\title{
DETERMINING TRAVEL CONDITIONS ON MOTORWAYS FOR AUTOMOBILE TRANSPORT BASED ON THE CASE STUDY FOR LITHUANIAN HIGHWAYS
}

\author{
Kazys PETKEVIČIUS ${ }^{1}$, Lijana MASKELIŪNAITE் ${ }^{2,3^{*}}$, Henrikas SIVILEVIČIUS ${ }^{4 *}$ \\ 1,2,4Transport and Logistics Competence Centre, Vilnius Gediminas Technical University, Lithuania \\ ${ }^{3}$ Dept of Transport Management, Vilnius College of Technologies and Design, Lithuania
}

Received 17 November 2017; revised 23 March 2018; accepted 30 June 2018

\begin{abstract}
In Lithuania, the efforts are made to ensure the conditions of safe, comfortable and fast passenger and freight transportation on Lithuanian roads, satisfying geometric characteristics of their particular categories and the specified requirements to their pavement. The considered characteristics of pavement include its roughness, strength and the admissible rut depth and destruction level. Rest and Service Areas (RSAs) are usually set up at the roadside. The paper presents a description of the conditions specified for the movement of motor vehicles on the major Lithuanian roads in the seasons of warm weather and a Classification Model (CM) of the required conditions. It also provides the results of the evaluation of actual Travel Conditions (TCs) on the main Lithuanian roads by using the developed model. The obtained results show that in 2016 on the considered highways were good and very good, except for road A9, where the TCs were satisfactory. It is demonstrated that the distances between RSAs comply with the recommended distances. It is also shown that roughness of pavement and strength of the Structure of the Pavement (SP) depend on the destruction or damage level of pavement. The values of such pavement parameters as roughness, rut depth and destruction level, which should not be exceeded because they help to ensure either comfortable or good TCs on Lithuanian highways, are given. The suggested model of road TCs can be used for determining the quality of TCs on highways.
\end{abstract}

Keywords: motorways, travel conditions, structure of the pavement, pavement, rest and service areas, roadside landscape.

\section{Introduction}

In any country, roads are important routes for vehicles, allowing people to move freely at a high speed in the desired directions and to reach the place of destination. The programme for maintenance and development of the main (most important) motorways of Lithuanian Republic for $2002 . . .2015$, as well as the programme developed for the period until 2020 , specify the requirement to largely improve the reliability of road transport infrastructure. The appropriate allocation of funds to road maintenance ensures a reasonable service life of roads and their pavements.

The regulations KPT SDK 07 (LAKD 2007) and KTR 1.01:2008 (LAKD 2008) clearly state and describe the conditions for designing highways and roads of categories $1 . . .5$ and determine the strength (class/group) of Structures of the Pavement (SP). The width and other metric parameters assigned to roads (according to their catego- ries), which are given in Tables 1 and 2, guarantee the specified design speed, $v_{p}^{(n)}[\mathrm{km} / \mathrm{h}]$.

The conditions of the pavement and the SP depend on the strength of the SP, which is specified by regulation KPT SDK 07 (LAKD 2007). However, the conditions of road travel are not fully described by specifications. They also depend on the safety of travel, its comfort, attractiveness and rate of movement, while the latter, in turn, depend on the condition of pavement, road signs and road surface marking, speed recording or decreasing devices and other engineering equipment, as well as distribution of rest and service areas (RSAs) and the attractiveness of roadside landscape (Samuchoviene et al. 2013).

The effectiveness of transportation is also influenced by the environmental and social factors, depending on the quality of services provided in travel (Han, Do 2016). A trip is comfortable, when roads and their surroundings are

${ }^{\star}$ Corresponding author. E-mail: lijana.maskeliunaite@vgtu.lt

\#Editor of the TRANSPORT - the manuscript was handled by one of the Associate Editors, who made all decisions related to the manuscript (including the choice of referees and the ultimate decision on the revision and publishing).

Copyright (C 2019 The Author(s). Published by VGTU Press

This is an Open Access article distributed under the terms of the Creative Commons Attribution License (http://creativecommons.org/licenses/by/4.0/), which permits unrestricted use, distribution, and reproduction in any medium, provided the original author and source are credited. 
attractive and there are RSAs on the roadside (Wang, Easa 2016). In defining the conditions of the vehicle's movement along the road, the largest admissible distances between these areas are specified.

To ensure the described Travel Conditions (TCs), the specified values of quality criteria of asphalt concrete or other type of pavement should be satisfied. Thus, the roughness of the pavement according to International Roughness Index (IRI) $Y_{I R T}$, should satisfy the condition $Y_{I R I} \leq Y_{I R I}^{(\text {perm })}$, the level of pavement destruction $D$ should be $D \leq D_{\text {perm }}$, and pavement rutting index $H$ should be $H \leq H_{\text {perm }}$ (where $R_{\text {perm }}$ is the admissible index value) (Petkevičius et al. 2006). The following road characteristics, corresponding to its category, should be taken into account: the width of the roadway $b_{v}$, the width of the pavement $b_{d}$, the width of the roadside (shoulder) $b_{k}$, the road width $b$, the width of the road and its protected zone $B$, etc. To implement the specified TCs for road transport, visibility range of the road, corresponding to the road category and importance as well as its protected zone should be guaranteed. The parameters corresponding to the road category, which are guaranteed, are as follows: the falling gradients of longitudinal $i_{i}$ and transverse $i_{s}$ road profiles and the lengths of the radii of the horizontal curves in the plan $R_{p}$, as well as the convex $R_{i s}$ and the concave $R_{i g}$ curves in the longitudinal profile (Samuchovienè et al. 2013).

Nonstructural factors, such as surface distresses and ride quality, have been commonly used as the main indicators of in-service pavement conditions. In the last decade, the concept of implementing a structural condition index in Pavement Management System (PMS) to complement functional condition indices has become an important goal for many highway agencies (Elbagalati et al. 2016).

In recent years, the intensity of road pavement destruction has been increasing and its service life has been decreasing because of the detrimental effect of the increasing flow of Heavy Transport (HT) on the pavement. The study of Lithuanian highways (Sivilevičius, Vansauskas 2013) has shown that the value of the rut depth on bituminous concrete pavement $H_{\max }$ approached the limiting value $H_{\text {lim }}=40 \mathrm{~mm}$. Thus, $H_{\max }=36.4 \mathrm{~mm}$ was determined on the road A1, while $H_{\max }=39.3 \mathrm{~mm}$ was found on the road A2. When the rut depth is greater than allowable limit the pavement are recycled (Vislavičius, Sivilevičius 2013).

The objective characteristic of pavement is the level of its destruction $D$ (Petkevičius 2008; Haas et al. 2006). The factors causing pavement destruction are closely interrelated, which makes it difficult to determine the cause of pavement destruction based on the type of damage and factors strongly influencing the formation of defects and their spread over the pavement (Mun 2014). The main causes of defect (flaw) formation are as follows: a weak SP, too strong destructive effect of HT on road pavement, unfavourable climatic conditions of the area and sprinkling as well as sensitivity of the road bed soil to frost (Petkevičius 2008; Yaromko 2008; Bertulienè et al. 2018).

The factors (criteria) determining the state of asphalt pavement under various operating conditions have been considered in many works (Mturi et al. 2014; Geng et al. 2014; Mallick et al. 2015; Mathew, Isaac 2014; Mubaraki 2014; Praticò 2015; Chamorro, Tighe 2015). Their analysis has shown that the state (condition) of pavement depends on the quality of the pavement material layer, its operating conditions and time of operation. Pavement conditions significantly influence the generation of nuisances that influence the environment and increase the costs borne by society. The Pavement Environmental Impact Model (PEIM) is the first attempt to adapt the Impact Pathway Approach (IPA) to assess the emission, dispersion, and impact of noise, air pollution, and greenhouse gases so that environmental impacts can be included in the economic models of pavement management units (Pellecuer et al. 2014).

The paper by Lee et al. (2015) focuses on the development of the relationship between poor pavement conditions and crash severity levels using a series of Bayesian ordered logistic models for low/medium/high speed roads and single/multiple collision cases. Solatifar et al. (2017) presents a simple method to determine dynamic modulus master curve of asphalt layers by conducting Falling Weight Deflectometer (FWD) for use in mechanisticempirical rehabilitation. Results showed that proposed method has several advantages over Mechanistic-Empirical Pavement Design Guide (MEPDG) including:

- simplicity in directly constructing in-situ dynamic modulus master curve;

- developing in-situ master curve in the same trend with the main predicted one;

- covering the large differences between in-situ and predicted master curve in high frequencies;

- the value obtained for the in-situ dynamic modulus is the same as the value measured by the FWD for a corresponding frequency.

Qin et al. (2015) have recommended the evaluation of the medical service provided in the case of the road accident in rural locality. In other paper (Qin et al. 2016), the scale for evaluating the roadside landscape based on its aesthetic value has been given. The landscape of the road, its pavement (and the adjacent area) has no clear boundaries. The particular landscape elements are often the constitutive parts of the road pavement.

Roadway safety involves the three components of the rodway system: the people, the vehicle, and the roadway. When the design corresponds to what the driver hopes to find, the road is consistent; the most widely used methods to evaluate design consistency are based on analysis of the operating speed profil. When the roadway aligment does not violate driver expectations, the possibility of drivers making errors is reduced (Dell'Acqua 2015). According to the study by Russo et al. (2014), based on the network approach for the allocation of economic resources and planning of road safety strategies, calibration of injury crash rate prediction models for specific target collision type important because of the range of harms that are caused by different collision types. 
Trafic signs are important roadway assets that provide critical guidance including regulations and safety-related information to road users (Ai, Tsai 2015). The effectiveness of a traffic sign is collectively influenced by the sign's understandability, legibility distance, glanclegibility, and learnability; however, understandability has been repeatedly identified as one the most important effectiveness measures (Neill et al. 2016).

The quality of road transport infrastructure was a substantial impact on tourism development in the country. The tourism industry has boomed recently, substantially increasing tourists and product values, but its support industries (e.g. restaurants, hotels, transportation networks) are responsible for heigh energy consumption rates, with serious environmental impacts (Chu, Chung 2016; Lin, Goay 2016).

The specifications define and the investigations consider TCs on motor roads from various perspectives (by assessing the road category and strength of its pavement, the factors ensuring a good state of the road, the medical services provided by the roads, the aesthetic perception of roadside landscape by the travellers, etc.). However, TCs have not been thoroughly investigated yet.
The aim of the present work is the development of a Classification Model (CM) of the actual automobile TCs on Lithuanian roads in the warm weather seasons and its applicability assessment, as well as the evaluation of TCs on the highways A1, A2, A9 and A11 by using the developed model.

\section{The object of research and the applied investigation methods}

The object of the present research is associated with TCs on the main highways of Lithuania specified for the warm weather seasons, the use of the developed $\mathrm{CM}$ of these conditions (Figure 1) and the ways of ensuring the specified TCs on the highways A1, A2, A9 and A11. In the research, the criteria describing operating pavement characteristics on the particular routes (Vilnius-Kaunas-Klaipėda (A1), Vilnius-Ukmergè-Panevėžys (A2), Panevėžys-Radviliškis-Šiauliai (A9), Šiauliai-KretingaPalanga (A11) and on Panevežys by-pass (A17)), such as pavement roughness (based on IRI), $Y_{I R I}[\mathrm{~m} / \mathrm{km}]$, its destruction level based on $D$ index [\%] (Petkevičius 2008) and the developed defects based on the rut depth index

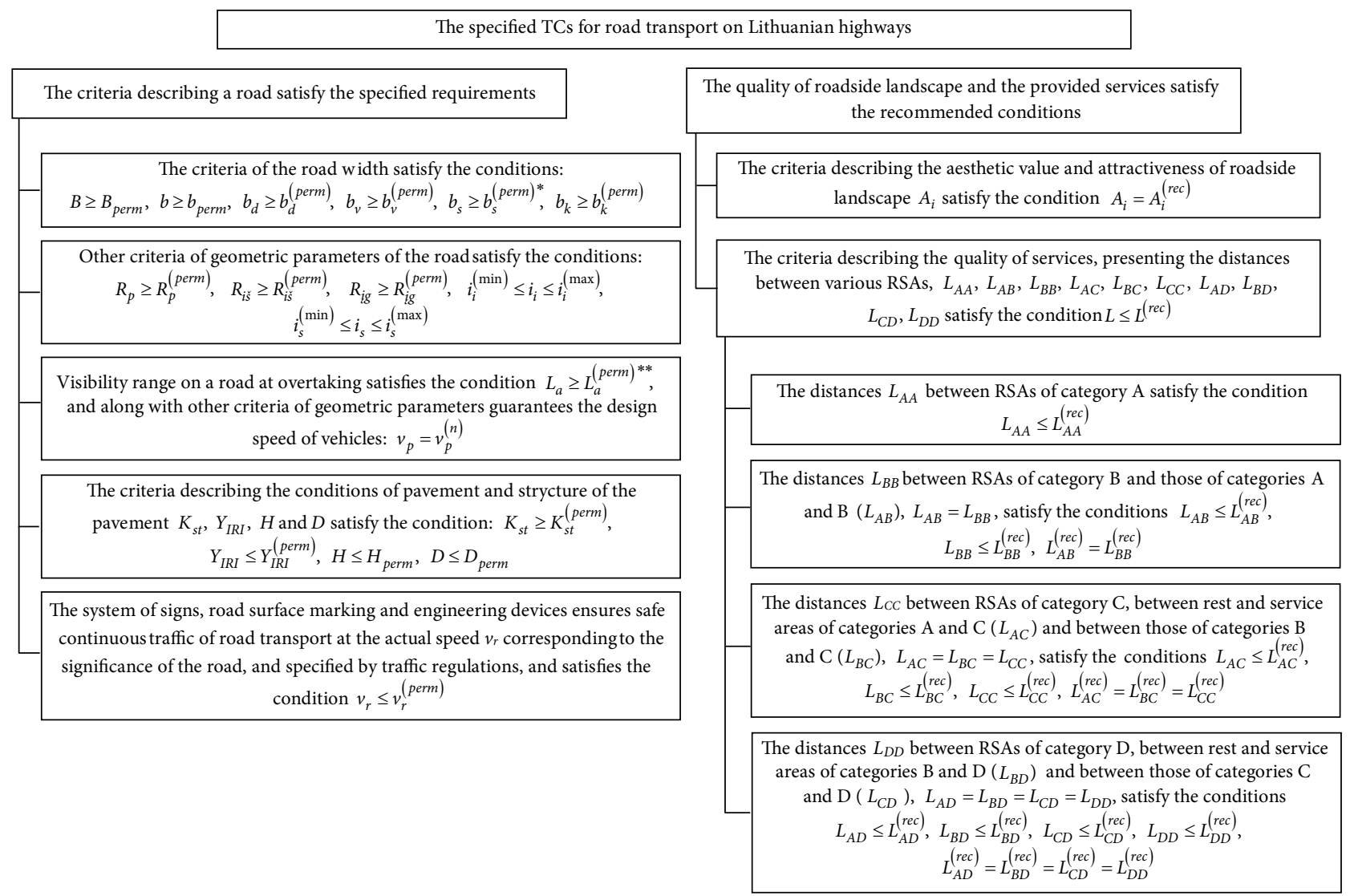

Figure 1. A CM of the specified TCs for road transport on the major Lithuanian highways (with the provided symbols, the admissible criteria values and the conditions of satisfying the requirements by the criteria defined in Tables 1 and 2$) ; K_{s t}^{(p e r m)}$ is the admissible value of pavement strength criterion $K_{s t}$; the values $K_{s t}^{(\text {perm })}$ of the criterion $K_{s t}$ for highways and for the roads of categories $1 . . .5$ are given in the work (Petkevičius 2008); ${ }^{*}$ the criteria $b_{s}$ and $b_{s}^{(\text {perm })}$ are determined only for the roads of categories 1 and 2 ; ${ }^{* *}$ the criteria $L_{a}$ and $L_{a}^{(\text {perm })}$ are determined for the roads of the 2 nd and lower categories 
$H_{\max }[\mathrm{mm}]$, were analysed. The considered roads are the major routes for travelling by road transport on Lithuanian territory from its capital Vilnius to the Baltic Sea. The Annual Average Daily Traffic (AADT) volume $N$ varies on different road sections from the smallest amount of vehicles $N_{\min }=8$ thous. vehicles/day to the largest amount $N_{\max }=45$ thous. vehicles/day. In performing the research, the problems given below were defined, analysed and (or) assessed:

- rapid worsening of the operating conditions of pavement described by the indices $Y_{I R I}, D$ and $H$;

- the requirements to the admissible values of pavement indices: roughness $Y_{I R I}^{(\text {perm })}$, rut depth $H_{\text {perm }}$ and destruction level $D_{\text {perm }}$;

- the location of the rest areas with hotels, motels, restaurants, cafes, petrol (gas) stations and with and without sheds;

- the periods between the overhauls (repairs) of the pavement of separate sections of the highways A1, A2, A9 and A11;

- the lengths [\%] of the roads A1, A2, A9, A11 satisfying the specified TCs on Lithuanian highways given in the CM (Figure 1), and the applicability of this model.

The total length of the considered highways A1, A2, A9, A11 and A17 is $682.0 \mathrm{~km}$, which makes about $39 \%$ of the total length of all Lithuanian roads, reaching $1750 \mathrm{~km}$.

The methods used in the research are as follows:

- summarizing and modelling TCs for road transport on Lithuanian motorways;

- observing the variation in the width of the motorway elements (i.e. pavement width $b_{d}$, roadway width $b_{v}$ and shoulder width $b_{k}$ ) on the sections of each investigated road, where visual inspection could show a reduction in the width of the road elements by comparing $30 . . .40$ width values and the width $b_{s}(n=30$ ... 40 width values);

- determining the values of indices $Y_{I R I}, H$ and $D$, showing the condition of road pavement along the length of the road (on each investigated road section with $l=20 \mathrm{~m}$ ) by using the Mobile Laboratory RST 28;

- determining the time periods between the repairs of the pavement of the roads A1, A2, A9 and A11;

- developing a model of the distribution of the RSAs on the roadside of Lithuanian highways;

- determining the real places for creating the RSAs along the roads A1, A2, A9, A11 and A17 and the aesthetic value of the roadside landscape $A_{i}$;

- using the correlation and regression analyses of the mathematical-statistical characteristics (such as the mean values $\bar{x}$ and standard deviations $s$ of the considered criteria).

The paper presents the results obtained in the research into the distribution of the RSAs on the roadside of high- ways performed in 2001, 2015 and 2016 and the data obtained in the comparative analysis of the results for 2001 and 2016.

\section{A model of the TCs on roads and its application to the investigation of highways}

In developing the CM of road TCs in warm weather seasons (Figure 1), the authors used various criteria to describe them (Table 1).

The developed CM (Figure 1) shows that the specified road TCs can be implemented only when the use of the admissible (or recommended) values of all the criteria of the road (Table 1) is guaranteed. The admissible and recommended values of the criteria describing TCs on highways are given in Table 2 .

The authors performed the study of quality characteristics of roads A1, A2, A9 and A11 described by the respective criteria by using a CM (Figure 1) and the admissible or recommended values of the considered criteria. The algorithm of the CM (Figure 1) application to the analysis is presented in Figure 2. It has been found, which road sections expressed in parts of the road length [\%] satisfy the TCs and which road sections fail to satisfy them. Only the values of the criteria (Table 2), which could vary during the service life of a road, i.e. the actual values of the criteria $b_{s}, b_{v}, b_{d}, b_{k}, Y_{I R I}, H, D, A_{i}$ and the distances $L_{A A}$, $L_{A B}, L_{B B}, L_{A C}, L_{B C}, L_{C C}, L_{A D}, L_{B D}, L_{C D}, L_{D D}$, as well as the distribution density of the RSAs on the roadside of the roads A1, A2, A17, A9 and A11, have been determined. The values of other criteria (Table 2), which do not change with time, have not been considered. AADT volume $N$ on the roads was in the range of the admissible values, while the speed $v_{r}$ values were restricted by the road signs, limiting the speed of vehicles.

The concept of the roadside and native land landscape is described in the work (Budriūnas, Ėringis 2000). The native land landscape is perceived there as a complex geoecological and cultural system consisting of the interrelated natural and anthropogenic components, while landscape is assumed to be the native land landscape in the visibility range.

In determining the mean values $\bar{T}_{d}$ and standard deviations $s_{T}$ of the time periods between pavement repairs of the roads A1, A2, A9 and A11, the actual values of the time periods between the pavement repairs of particular road sections (from the 1 st $T_{d}^{(1)}$ to the $n$-th $T_{d}^{(n)}$ ) $T_{d}$ were used:

$$
\begin{aligned}
& \bar{T}_{d}=\frac{1}{n} \cdot\left(T_{d}^{(1)}+T_{d}^{(2)}+\ldots+\right. \\
& \left.T_{d}^{(i)}+\ldots+T_{d}^{(n)}\right)=\frac{1}{n} \cdot \sum_{i=1}^{n} T_{d}^{(i)} ; \\
& s_{T}=\sqrt{\frac{1}{n-1} \cdot \sum_{i=1}^{n}\left(T_{d}^{(i)}-\bar{T}_{d}\right)^{2}} .
\end{aligned}
$$


Table 1. The criteria describing the specified TCs on major Lithuanian highways for road transport, their limiting values and the conditions required for their satisfaction

\begin{tabular}{|c|c|c|c|c|}
\hline $\begin{array}{l}\text { The criteria } \\
\text { of the road }\end{array}$ & $\begin{array}{l}\text { The criteria describing TCs and their } \\
\text { units of measure }\end{array}$ & $\begin{array}{l}\text { The } \\
\text { criterion } \\
\text { symbol }\end{array}$ & $\begin{array}{l}\text { The limiting values of criteria, their } \\
\text { symbols and units of measure }\end{array}$ & $\begin{array}{l}\text { The conditions } \\
\text { needed for the } \\
\text { criteria to satisfy } \\
\text { the requirements }\end{array}$ \\
\hline \multirow{14}{*}{$\begin{array}{l}\text { The criteria } \\
\text { describing } \\
\text { the road } \\
\text { category and } \\
\text { significance }\end{array}$} & $\begin{array}{l}\text { The road width (with the protected } \\
\text { zone) }[\mathrm{m}]\end{array}$ & $B$ & $\begin{array}{l}\text { The smallest admissible width value } \\
\text { (and its protected zone) } B_{\text {perm }}[\mathrm{m}]\end{array}$ & $B \geq B_{\text {perm }}$ \\
\hline & The road width $[\mathrm{m}]$ & $b$ & $\begin{array}{l}\text { The smallest admissible value of the road } \\
\text { width } b_{\text {perm }}[\mathrm{m}]\end{array}$ & $b \geq b_{\text {perm }}$ \\
\hline & The width of the roadway $[\mathrm{m}]$ & $b_{v}$ & $\begin{array}{l}\text { The smallest admissible width value } \\
\text { of the roadway } b_{v}^{(\text {perm })}[\mathrm{m}]\end{array}$ & $b_{v} \geq b_{v}^{(\text {perm })}$ \\
\hline & $\begin{array}{l}\text { The width of the pavement (roadway, } \\
\text { safety and stopping lanes) [m] }\end{array}$ & $b_{d}$ & $\begin{array}{l}\text { The smallest admissible width value } \\
\text { of the pavement } b_{d}^{(\text {perm })}[\mathrm{m}]\end{array}$ & $b_{d} \geq b_{d}^{(p e r m)}$ \\
\hline & The width of the wayside (shoulder) [m] & $b_{k}$ & $\begin{array}{l}\text { The smallest admissible width value } \\
\text { of the wayside (shoulder) } b_{k}^{(\text {perm })}[\mathrm{m}]\end{array}$ & $b_{k} \geq b_{k}^{(\text {perm })}$ \\
\hline & $\begin{array}{l}\text { The width of the reserved area } \\
\text { separating lanes of traffic on the road } \\
\text { (only for highways and roads } \\
\text { of categories } 1 \text { and } 2 \text { ) [m] }\end{array}$ & $b_{s}$ & $\begin{array}{l}\text { The smallest admissible width of the } \\
\text { reserved area separating lanes of traffic on } \\
\text { the road } b_{s}^{(\text {perm })}[\mathrm{m}]\end{array}$ & $b_{s} \geq b_{s}^{(\text {perm })}$ \\
\hline & $\begin{array}{l}\text { The length of the radius of the curves } \\
\text { of the roads in the plan (horizontal } \\
\text { curves) [m] }\end{array}$ & $R_{p}$ & $\begin{array}{l}\text { The smallest admissible value of the radius } \\
\text { length of the curves of the roads in the plan } \\
\text { (horizontal curves) } R_{p}^{(\text {perm) }}[\mathrm{m}]\end{array}$ & $R_{p} \geq R_{p}^{(\text {perm })}$ \\
\hline & $\begin{array}{l}\text { The length of the radius of the convex } \\
\text { vertical curves of the road }[\mathrm{m}]\end{array}$ & $R_{i \check{s}}$ & $\begin{array}{l}\text { The smallest admissible value of the radius } \\
\text { length of the convex vertical curves of the } \\
\text { road } R_{i s}^{(\text {perm })}[\mathrm{m}]\end{array}$ & $R_{i \check{s}} \geq R_{i \check{s}}^{(\text {perm })}$ \\
\hline & $\begin{array}{l}\text { The length of the radius of the concave } \\
\text { vertical curves of the road }[\mathrm{m}]\end{array}$ & $R_{i g}$ & $\begin{array}{l}\text { The smallest admissible value of the radius } \\
\text { length of the concave vertical curves } \\
R_{i g}^{(\text {perm })}[\mathrm{m}]\end{array}$ & $R_{i g} \geq R_{i g}^{(\text {perm })}$ \\
\hline & Longitudinal slope of the road [\%] & $i_{i}$ & $\begin{array}{l}\text { The minimal } i_{i}^{(\min )} \text { and the maximal } i_{i}^{(\max )} \\
\text { admissible values of the longitudinal slope } \\
\text { of the road [\%] }\end{array}$ & $i_{i}^{(\min )} \leq i_{i} \leq i_{i}^{(\max )}$ \\
\hline & Cross slope of the road [\%] & $i_{s}$ & $\begin{array}{l}\text { The minimal } i_{i}^{(\min )} \text { and the maximal } i_{i}^{(\max )} \\
\text { admissible values of the cross slope of the } \\
\text { road [\%] }\end{array}$ & $i_{s}^{(\min )} \leq i_{s} \leq i_{s}^{(\max )}$ \\
\hline & $\begin{array}{l}\text { The range of visibility at overtaking } \\
\text { (only for roads of categories } 2 \ldots 5 \text { ) [m] }\end{array}$ & $L_{a}$ & $\begin{array}{l}\text { The smallest admissible value of the range } \\
\text { of visibility at overtaking } L_{a}^{(\text {perm })}[\mathrm{m}]\end{array}$ & $L_{a} \geq L_{a}^{(\text {perm })}$ \\
\hline & The design speed of a vehicle $[\mathrm{km} / \mathrm{h}]$ & $v_{p}$ & $\begin{array}{l}\text { The specified design speed of a vehicle } \\
v_{p}^{(n)}[\mathrm{km} / \mathrm{h}]\end{array}$ & $v_{p}=v_{p}^{(n)}$ \\
\hline & $\begin{array}{l}\text { The actual admissible speed } \\
\text { of a vehicle }[\mathrm{km} / \mathrm{h}]\end{array}$ & $v_{r}$ & $\begin{array}{l}\text { The admissible speed of a vehicle (limited } \\
\text { by the road signs) } v_{r}^{(\text {perm })}[\mathrm{km} / \mathrm{h}]\end{array}$ & $v_{r} \leq v_{r}^{(\text {perm })}$ \\
\hline \multirow{4}{*}{$\begin{array}{l}\text { The criteria } \\
\text { describing } \\
\text { the } \\
\text { condition } \\
\text { of pavement } \\
\text { and SP }\end{array}$} & $\begin{array}{l}\text { The criteria of pavement, in decimal } \\
\text { fractions }(>1.0 \text { or } \leq 1.0)\end{array}$ & $K_{s t}$ & $\begin{array}{l}\text { The smallest admissible value } K_{s t}^{(p e r m)} \\
\text { of SP strength } K_{s t} \text { [in decimal fractions] }\end{array}$ & $K_{s t} \geq K_{s t}^{(p e r m)}$ \\
\hline & IRI $[\mathrm{m} / \mathrm{km}]$ & $Y_{I R I}$ & $\begin{array}{l}\text { The largest admissible value } Y_{\text {IRI }}^{(\text {perm })} \\
\text { of IRI }[\mathrm{m} / \mathrm{km}]\end{array}$ & $Y_{I R I} \leq Y_{I R I}^{(\text {perm })}$ \\
\hline & The level of pavement destruction [\%] & $D$ & $\begin{array}{l}\text { The largest admissible value of pavement } \\
\text { destruction } D_{\text {perm }}[\%]\end{array}$ & $D \leq D_{\text {perm }}$ \\
\hline & Pavement rutting (rut depth) $[\mathrm{mm}]$ & $H$ & $\begin{array}{l}\text { The largest admissible value of pavement } \\
\text { rut depth } H_{\text {perm }}[\mathrm{mm}]\end{array}$ & $H \leq H_{\text {perm }}$ \\
\hline $\begin{array}{l}\text { The criteria } \\
\text { describing } \\
\text { roadside } \\
\text { landscape }\end{array}$ & $\begin{array}{l}\text { The aesthetic value of roadside } \\
\text { landscape [points] }\end{array}$ & $A_{i}$ & $\begin{array}{l}\text { The recommended value of the criterion } \\
\text { describing the aesthetics of roadside } \\
\text { landscape } A_{i}^{(\text {rec })} \text { [points] }\end{array}$ & $A_{i}=A_{i}^{(r e c)}$ \\
\hline
\end{tabular}


End of Table 1

\begin{tabular}{|c|c|c|c|c|}
\hline $\begin{array}{l}\text { The criteria } \\
\text { of the road }\end{array}$ & $\begin{array}{l}\text { The criteria describing TCs and their } \\
\text { units of measure }\end{array}$ & $\begin{array}{l}\text { The } \\
\text { criterion } \\
\text { symbol }\end{array}$ & $\begin{array}{l}\text { The limiting values of criteria, their } \\
\text { symbols and units of measure }\end{array}$ & $\begin{array}{l}\text { The conditions } \\
\text { needed for the } \\
\text { criteria to satisfy } \\
\text { the requirements }\end{array}$ \\
\hline \multirow{5}{*}{$\begin{array}{l}\text { The criteria } \\
\text { describing } \\
\text { the quality } \\
\text { of services } \\
\text { provided in } \\
\text { the roadside } \\
\text { areas }\end{array}$} & The distance between the RSAs $[\mathrm{km}]$ & $L$ & $\begin{array}{l}\text { The largest recommended value of the } \\
\text { distance between the RSAs } L^{(r e c)}[\mathrm{km}]\end{array}$ & $L \leq L^{(r e c)}$ \\
\hline & $\begin{array}{l}\text { The distance between the RSAs } \\
\text { of category A [km] }\end{array}$ & $L_{A A}$ & $\begin{array}{l}\text { The largest recommended value of the } \\
\text { distance between the RSAs of category A } \\
L_{A A}^{(r e c)}[\mathrm{km}]\end{array}$ & $L_{A A} \leq L_{A A}^{(r e c)}$ \\
\hline & $\begin{array}{l}\text { The distance between the RSAs } \\
\text { of categories A and B }[\mathrm{km}]\end{array}$ & $L_{A B}$ & $\begin{array}{l}\text { The largest recommended value of the } \\
\text { distance between the RSAs of categories A } \\
\text { and B } L_{A B}^{(r e c)}[\mathrm{km}]\end{array}$ & $L_{A B} \leq L_{A B}^{(r e c)}$ \\
\hline & $\begin{array}{l}\text { The distance between the RSAs } \\
\text { of categories A and C [km] }\end{array}$ & $L_{A C}$ & $\begin{array}{l}\text { The largest recommended value of the } \\
\text { distance between the RSAs of categories A } \\
\text { and } C L_{A C}^{(\text {rec })}[\mathrm{km}]\end{array}$ & $L_{A C} \leq L_{A C}^{(r e c)}$ \\
\hline & $\begin{array}{l}\text { The distance between the RSAs } \\
\text { of categories A and D [km] }\end{array}$ & $L_{A D}$ & $\begin{array}{l}\text { The largest recommended value of the } \\
\text { distance between the RSAs of categories A } \\
\text { and D } L_{A D}^{(\text {rec })}[\mathrm{km}]\end{array}$ & $L_{A D} \leq L_{A D}^{(r e c)}$ \\
\hline
\end{tabular}

Notes:

1) the criteria describing TCs, which are given in the table, have a direct influence on the quality of travel for vehicle drivers and passengers;

2) the limiting values of the criteria given in the table are the values corresponding to the road category and complying with the requirements of the code (LAKD 2008); the width of the protected zone of the road is defined by the law on the roads of Lithuanian Republic. These values are also given in the work of (Samuchovienè et al. 2013);

3) the defined traffic safety measures (the provision of the required road signs, road surface marking, engineering equipment, etc.) are guaranteed by the requirements of regulations, specifications and traffic rules for road transport;

4) The aesthetic value (attractiveness) of the roadside landscape is described by the criterion $A_{i}$ and expressed in points 1,2 or 3 , according to the methodology suggested in (Budriūnas, Ėringis 2000);

5) the largest recommended values of the distances between the RSAs $\left(L_{A A}^{(\mathrm{rec})}, L_{A B}^{(\mathrm{rec})}, L_{A C}^{(\mathrm{rec})}, L_{A D}^{(\mathrm{rec})}\right)$ are given in Table 2;

6) the criteria indices of the condition of pavement $Y$ and $H$ are specified by (LAKD 2014), while the values $D_{\text {perm }}$ of criterion $D$ and the values $K_{s t}^{(p e r m)}$ of criterion $K_{s t}$ are given in the work (Petkevičius 2008).

The admissible values $T_{d}^{(\text {perm })}$ of the time periods between the pavement repairs differ, depending on the operating conditions of pavement. The admissible values $T_{d}^{(p e r m)}$ of the pavement criterion $T_{d}$ depend on the period when the conditions of the compliance of pavement criteria values with the specified values for various road sections $\left(Y_{I R I} \leq Y_{I R I}^{(\text {perm })}, H \leq H_{\text {perm }}, D \leq D_{\text {perm }}\right)$ can be observed. When the actual value $\left(Y_{I R I}^{(f)}, H_{f}\right.$ or $\left.D_{f}\right)$ of at least a single road pavement criterion $\left(Y_{I R I}, H\right.$ or $\left.D\right)$ changes so that it does not satisfy the condition $Y_{I R I}^{(f)} \leq Y_{I R I}^{(p e r m)}$, $H_{f} \leq H_{\text {perm }}$ or $D_{f} \leq D_{\text {perm }}$, pavement should be repaired because the actual time period $T_{d}^{(f)}$ between pavement repairs $T_{d}^{(f)}=T_{d}^{(\text {perm })}$ of this road section has elapsed.

When other criteria values of road sections do not satisfy the required values (Table 2, Figure 2), these road sections are repaired to meet the specified conditions, while when the distances between the RSAs do not satisfy the condition $L \leq L^{(\text {rec })}$ (Figure 1, Table 2), the lacking RSAs are set up beside a road.

The values of the criteria $A_{i}$ describing the aesthetical attractiveness of landscape are estimated against the scale of 3 points (1,2 and 3 ) according to the method suggested in research by Budriūnas, Éringis (2000). The value of the most attractive landscape is $A_{i}=3$, the value of medium attractiveness is $A_{i}=2$, while the lowest landscape attractiveness value is $A_{i}=1$. When this value is smaller than $A_{i}^{(\text {rec })}=3$ (Table 2), unattractive areas are made attractive by improving their relief and by planting more trees, flowers, etc.

In the CM (Figure 1), the RSAs are divided into categories (A, B, C and D) according to the planned periods of rest (from the highest category, $A$, to the lowest category, D). The longest rest period $(\geq 10 \mathrm{~h})$ is provided for vehicle drivers and passengers in RSAs of category A, while for RSAs of category B this period is $\geq 1 \ldots 2 \mathrm{~h}$, for RSAs of category $\mathrm{C}-\geq 0.5 \ldots 1.0 \mathrm{~h}$ and for RSAs of category $\mathrm{D}-\leq 0.5 \mathrm{~h}$.

One or more parking lots are established for vehicles in RSAs of any category. The number of parking places matches the number of people that can be serviced at the RSA.

RSAs are divided into categories according to their most important structures (objects) determining the rest duration of RSAs. RSA is awarded category A when it has a hotel or motel, $\mathrm{B}$ when it has a restaurant, $\mathrm{C}$ when it has a café and/or a gas station and D when it is an ordinary ground for rest (with or without a shed) and has a table (tables) and a bench (benches). RSAs of categories A, B and $C$ providing a variety of services are referred to as rest and service complexes (RSCs). 


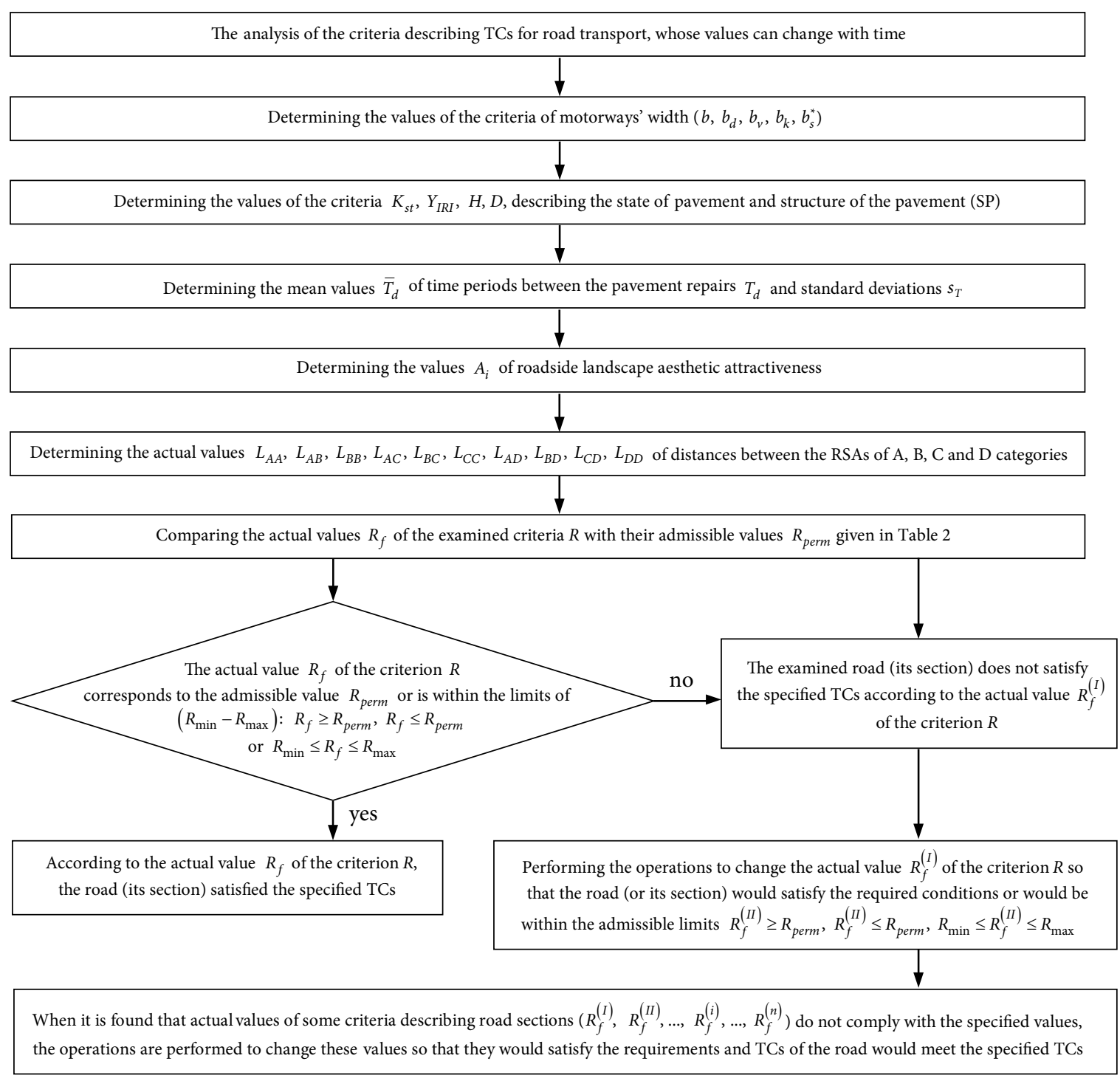

Figure 2. The algorithm of the application of the CM (Figure 1) to the investigation of highways for correcting the inappropriate road criteria values to satisfy the requirements (criterion $b_{s}^{*}$ applies only to highways and roads)

\section{The experimental study of the criteria describing the width of the motor road elements and the quality of pavement}

The performed study has shown that the width criteria $b_{v}, b_{d}, b_{k}$ and $b_{s}$ (on the total length of roads A1 and A2 and on road A9 and A11 sections of $11.4 \mathrm{~km}$ and 17.4 $\mathrm{km}$, respectively, where there is a reserved area separating traffic lanes) of the elements of roads A1, A2, A17, A9 and A11 fully (100\%) satisfied the requirements given in Table 2. The values of pavement condition on the highway A1 satisfied $99.3 \%$ of the requirements: $Y_{I R I}^{(f)} \leq 2.0 \mathrm{~m} / \mathrm{km}$, $H_{f} \leq 12 \mathrm{~mm}, D_{f} \leq 4.0 \%$. 14.6...21.3\% of the lengths of the examined roads A2, A17, A9 and A11 did not satisfy the pavement requirements (Table 3 ).

The results obtained (Table 3 ) show that the pavement of the examined sections of highway A1 was repaired in time, while the repairs of other roads' pavement were often made too late. Therefore, the examined road sections satisfied the pavement conditions (Table 2 ) only partially
(78.7...85.4\%). Under the conditions of insufficient pavement repair funding, the pavement of the roads with highly intense traffic is repaired first and only then the pavement of other roads, which also needs renewing, is repaired. This explains why $14.6 \ldots .21 .3 \%$ of the pavement length of these roads was not repaired in time.

The authors performed the analysis of the period between pavement repairs for the roads A1, A2, A9 and A11. The obtained results have shown that with the increase in the requirements to the criteria values describing the condition of pavement $\left(Y_{I R I}, H\right.$ and $\left.D\right)$ and the intensity of road traffic, the periods between repairs $T_{d}$ were getting shorter as follows: in 1987: $T_{d}=14$ years, in 2002: $T_{d}=9$ years (Petkevičius 2008) and in 2015: $T_{d}=8$ years ( $\mathrm{Ta}-$ ble 4). When the critical values $Y_{I R I}^{(\text {perm })}, H_{\text {perm }}$ and $D_{\text {perm }}$ of the criteria $Y_{I R I}, H$ and $D$ were reached for the roads A1 and $\mathrm{A} 2$, having the highest traffic intensity, their pavement was usually repaired in time. This led to the shortening of the periods between their pavement repairs to $T_{d}=8$ years. 
Table 2. The admissible and recommended values of the criteria describing TCs on Lithuanian highways in warm seasons

\begin{tabular}{|c|c|c|c|c|c|c|c|c|c|c|c|c|}
\hline \multirow{4}{*}{$\begin{array}{l}\text { The criterion describing TCs, } \\
\text { its symbol and unit of measure }\end{array}$} & \multicolumn{2}{|c|}{$\begin{array}{l}\text { The symbol of the } \\
\text { admissible value } \\
\text { of the criterion }\end{array}$} & \multicolumn{10}{|c|}{ The admissible value of the criterion } \\
\hline & \multirow{3}{*}{$\underset{(\min )}{\operatorname{minimal}}$} & \multirow{3}{*}{$\underset{(\max )}{\operatorname{maximal}}$} & \multicolumn{10}{|c|}{ Road category } \\
\hline & & & \multicolumn{2}{|c|}{$\mathrm{AM}$} & \multicolumn{2}{|c|}{1} & \multicolumn{2}{|c|}{2} & \multicolumn{2}{|c|}{$2 \mathrm{a}$} & \multicolumn{2}{|c|}{3} \\
\hline & & & $\min$ & $\max$ & $\min$ & $\max$ & $\min$ & $\max$ & $\min$ & $\max$ & $\min$ & $\max$ \\
\hline IRI $Y_{I R I}[\mathrm{~m}]$ & & $Y_{I R I}^{(\text {perm })}$ & & 2.0 & & 2.0 & & 2.5 & & 2.5 & & 2.5 \\
\hline $\begin{array}{l}\text { The level of pavement } \\
\text { destruction } D[\%]\end{array}$ & & $D_{\text {perm }}$ & & 4.0 & & 4.0 & & 8.0 & & 8.0 & & 8.0 \\
\hline Pavement rutting $H[\mathrm{~mm}]$ & & $H_{\text {perm }}$ & & 12 & & 12 & & 20 & & 20 & & 20 \\
\hline $\begin{array}{l}\text { The aesthetic value of roadside } \\
\text { landscape } A_{i} \text { [points] }\end{array}$ & $A_{i}^{(r e c)}$ & & 3 & & 3 & & 3 & & 3 & & 3 & \\
\hline $\begin{array}{l}\text { The distance } L_{A A} \text { between the } \\
\text { RSAs of category A }[\mathrm{km}]\end{array}$ & & $L_{A A}^{(r e c)}$ & & 19 & & 19 & & 19 & & 19 & & 19 \\
\hline $\begin{array}{l}\text { The distance } L_{A B} \text { between the } \\
\text { RSAs of categories A and B }[\mathrm{km}]\end{array}$ & & $L_{A B}^{(r e c)}$ & & 14 & & 14 & & 14 & & 14 & & 14 \\
\hline $\begin{array}{l}\text { The distance } L_{A C} \text { between the } \\
\text { RSAs of categories A and C }[\mathrm{km}]\end{array}$ & & $L_{A C}^{(r e c)}$ & & 7 & & 7 & & 7 & & 7 & & 7 \\
\hline $\begin{array}{l}\text { The distance } L_{A D} \text { between the } \\
\text { RSAs of categories A and } D[\mathrm{~km}]\end{array}$ & & $L_{A D}^{(r e c)}$ & & 5 & & 5 & & 5 & & 5 & & 5 \\
\hline
\end{tabular}

Notes:

1) the values specified for other criteria describing road category and significance are given in regulations KTR 1.01:2008 (LAKD 2008) and in the work (Samuchoviene et al. 2013);

2) the criterion $Y_{I R I}^{(\text {perm })}$ values for highways and 1st category roads correspond to the average maintenance level, while the values of criteria $Y_{I R I}^{(\text {perm })}$ and $H_{\text {perm }}$ of road categories $2,2^{\mathrm{a}}$ and 3 correspond to the low maintenance level;

3) the criterion $D$ values $D_{\text {perm }}$ specified for roads of categories $2,2^{\text {a }}$ and 3 are recommended in the work (Petkevičius 2008), while the values of criteria $D_{\text {perm }}$ and $H_{\text {perm }}$ for highways and roads of category 1 are such that satisfy $Y_{I R I}^{(\text {perm })}=2.0 \mathrm{~m} / \mathrm{km}$ (calculated by the Equations (3) and (4));

4) the present study has determined the criteria value by surveying 1689 Lithuanian citizens and 249 foreigners. Taking into account the opinions of $90 \%$ of people participating in the survey, the largest admissible values of the distances between the RSAs were accepted as the recommended values $L_{A A}^{(\mathrm{rec})}, L_{A B}^{(\mathrm{rec})}, L_{A C}^{(\mathrm{rec})}, L_{A D}^{(\mathrm{rec})}$;

5) the limiting values and symbols of criteria are given in Table 1 ;

6) the value $A_{i}=3$ of the criterion $A_{i}$ is used for describing an aesthetically attractive land.

Table 3. Pavement criteria values for the sections of highways A1, A2, A17, A9 and A11

\begin{tabular}{|c|c|c|c|c|c|}
\hline \multirow{2}{*}{ The data on the condition of the examined motor roads and their pavement } & \multicolumn{5}{|c|}{ Motor roads } \\
\hline & A1 & $\mathrm{A} 2$ & A17 & A9 & A11 \\
\hline Road length $[\mathrm{km}]$ & 311.00 & 127.50 & 11.50 & 82.00 & 150.00 \\
\hline The length of the examined pavement [km] & 293.00 & 117.50 & 10.50 & 67.00 & 146.85 \\
\hline The examined length of the roads [\%] & 94.21 & 92.16 & 91.30 & 81.71 & 97.90 \\
\hline $\begin{array}{l}\text { The length of the motor road sections whose pavement condition criteria } \\
\text { values }\left(Y_{I R I}^{(f)}, H_{f} \text { and } D_{f}\right) \text { satisfy the specified requirements (Table 2) }[\mathrm{km}]\end{array}$ & 291.00 & 100.35 & 8.26 & 53.10 & 124.05 \\
\hline $\begin{array}{l}\text { The examined part of the length of the roads where criteria values of } \\
\text { pavement condition satisfy all specified requirements (Table 2) [\%] }\end{array}$ & 99.32 & 85.40 & 78.67 & 79.25 & 84.47 \\
\hline
\end{tabular}

The periods between pavement repairs on the roads A9 and A11 are still longer (Table 4), therefore, the implementation of the specified TCs on these roads (with old and rough pavement) cannot be guaranteed.
The examination of Lithuanian highways has shown that, under the conditions of the increasing road traffic intensity and the percentage of HT on these roads, a close relationship between the pavement roughness $Y_{I R I}[\mathrm{~m} / \mathrm{km}]$ 
and the criteria $D[\%]$ and $H[\mathrm{~mm}]$ remained unchanged:

$$
\begin{aligned}
& Y_{I R I}=0.2765 \cdot D+1.09, R^{2}=0.877 ; \\
& Y_{I R I}=0.1464 \cdot H+0.29, R^{2}=0.913 .
\end{aligned}
$$

It has been found that the mean values of the criteria $D$ [\%], $H[\mathrm{~mm}]$ and $Y_{\text {IRI }}[\mathrm{m} / \mathrm{km}]$ are related to their standard deviations $s_{D}, s_{H}$ and $s_{Y}$ as follows:

$$
\begin{aligned}
& s_{D}=1.946 \cdot \bar{D}^{-0.732}, R^{2}=0.879 ; \\
& s_{H}=0.464 \cdot \bar{H}^{-0.867}, R^{2}=0.898 ; \\
& s_{Y}=0.397 \cdot \bar{Y}_{I R I}, R^{2}=0.651 .
\end{aligned}
$$

It has also been determined from Equations (3)-(7) that:

- to provide comfortable TCs on highways (when $\left.Y_{\text {IRI }} \leq 1.0 \mathrm{~m} / \mathrm{km}\right), \quad H \leq 5 \mathrm{~mm}$ and $D=0 \%$ should be ensured, while for reaching good TCs (when $\left.Y_{\text {IRI }} \leq 2.0 \mathrm{~m} / \mathrm{km}\right), H \leq 12 \mathrm{~mm}$ and $D \leq 4 \%$ should be maintained;

- when $Y_{I R I} \leq 1.0 \mathrm{~m} / \mathrm{km}$, the criterion $s_{Y}$ is $s_{Y} \leq$ $0.40 \mathrm{~m} / \mathrm{km}$; when $Y_{I R I} \leq 2.0 \mathrm{~m} / \mathrm{km}$ and $s_{Y} \leq$ $1.0 \mathrm{~m} / \mathrm{km}$, implying that when pavement roughness is getting lower, the uniformity of pavement roughness is decreasing even faster (e.g. when the index $Y_{I R I}$ is twice as large), the value of the criterion $s_{Y}$ increases by 2.5 times;

- to provide comfortable TCs, the pavement roughness uniformity values $s_{Y} \leq 0.40 \mathrm{~m} / \mathrm{km}$ and $s_{H} \leq 1.50 \mathrm{~mm}$ should be reached, while for providing good TCs, these values should be as follows: $s_{Y} \leq 1.0 \mathrm{~m} / \mathrm{km}$ and $s_{D} \leq 5.0 \%, s_{H} \leq 4.0 \mathrm{~mm}$.

\section{Determining aesthetic attractiveness of roadside landscape}

Visual inspection of roadside landscape of the roads A1 (E85), A2, A17, A9 and A11 (E272) has shown that the landscape of countryside and wasteland is attractive. Its criterion $A_{i}$ value was $A_{i}=3$. The landscape of the urban and suburban areas (Samuchoviene et al. 2013) was of medium attractiveness and the value of its evaluation criterion was $A_{i}=2$. The examined section of road A17 $(11.5 \mathrm{~km})$ is in the suburban landscape zone. The roadside landscape of the total length of the road $(11.5 \mathrm{~km})$ was evaluated to be $A_{i}=2$. The results obtained in the study are presented in Table 5 .

The results of the performed experimental study (Table 5) have shown that roadside landscape of roads A1 and A2 is most attractive, while the landscape of the road A17 is least attractive.

\section{The examination of the distribution of the RSAs along the roads and their schematic models}

\begin{tabular}{|c|c|c|c|c|}
\hline \multirow[b]{2}{*}{ The name of the road (route No) } & \multicolumn{3}{|c|}{ Statistical characteristics of time periods $T_{d}$} & \multirow{2}{*}{$\begin{array}{c}\text { The number of the } \\
\text { examined road } \\
\text { sections } n\end{array}$} \\
\hline & $\begin{array}{c}\text { the arithmetic mean } \\
\bar{T}_{d} \text { [years] }\end{array}$ & $\begin{array}{c}\text { standard deviation } \\
s_{T} \text { [years] }\end{array}$ & $\begin{array}{c}\text { variation coefficient } \\
V_{T}[\%]\end{array}$ & \\
\hline Vilnius-Kaunas-Klaipėda highway (A1) & 7.71 & 2.52 & 32.68 & 26 \\
\hline Vilnius-Panevėžys highway (A2) & 8.40 & 2.21 & 26.31 & 25 \\
\hline Highways A1 and A2 & 8.05 & 2.37 & 29.48 & 51 \\
\hline Panevėžys-Radviliškis-Šiauliai road (A9) & 9.80 & 2.60 & 26.53 & 24 \\
\hline Šiauliai-Kretinga-Palanga road (A11) & 9.60 & 2.50 & 26.04 & 28 \\
\hline Roads A9 and A11 & 9.70 & 2.55 & 26.29 & 52 \\
\hline
\end{tabular}

The performed experimental research (Table 6) has shown that RSAs were distributed along the roads A1, A2, A9 and

\begin{tabular}{|c|c|c|c|c|c|}
\hline \multirow{2}{*}{ The parameters of highways and description of their roadside landscape } & \multicolumn{5}{|c|}{ Motor roads } \\
\hline & A1 & A2 & A17 & A9 & A11 \\
\hline Road length [km] & 311.0 & $127.5(135.5)$ & 11.5 & 82.0 & 150.0 \\
\hline The length of the road section with the criterion value $A_{i}=3[\mathrm{~km}]$ & 259.0 & 117.5 & 0 & 58.5 & 118.0 \\
\hline The length of the road section with the criterion value $A_{i}=3[\%]$ & 83.3 & $92.2(86.7)$ & 0 & 71.3 & 78.7 \\
\hline The length of the road section with the criterion value $A_{i}=2[\mathrm{~km}]$ & 52.0 & $10.0(18.0)$ & 11.5 & 23.5 & 32.0 \\
\hline The length of the road section with the criterion value $A_{i}=2[\%]$ & 16.7 & $7.8(13.3)$ & 100 & 28.7 & 21.3 \\
\hline
\end{tabular}
A11 in a particular order.

Table 4. The statistical characteristics (2015) of the time periods between pavement repairs $T_{d}$ of the motor roads A1, A2, A9, A11

Table 5. The results of the study of roadside landscape for highways A1 (E85), A2, A17, A9 and A11 (E272)

Notes:

1) the section of the road A2, which is also the route of the road A8, belongs to Panevėzys and its suburb; the length of the road A2 is $135.5 \mathrm{~km}$; the route of the road A2 of $127.5 \mathrm{~km}$ belongs to the European road E272;

2) the data on the total length of the road A2 $(135.5 \mathrm{~km})$ are given in brackets. 
Table 6. The statistical characteristics (2001) of the distances between RSAs of categories A, B, C and $\mathrm{D}$ along the roads $\mathrm{A} 1, \mathrm{~A} 2, \mathrm{~A} 9$ and $\mathrm{A} 11$

\begin{tabular}{|c|c|c|c|c|c|c|c|c|c|c|c|}
\hline \multicolumn{12}{|c|}{$\begin{array}{l}\text { The statistical characteristics of the categories of the RSAs (the number of individual values } n \text {, mean values of the distances } \\
\text { between RSAs } \bar{L}[\mathrm{~km}] \text { and their standard deviations } s_{L}[\mathrm{~km}]\end{array}$} \\
\hline \multicolumn{3}{|c|}{ Category A } & \multicolumn{3}{|c|}{ Category B } & \multicolumn{3}{|c|}{ Category $\mathrm{C}$} & \multicolumn{3}{|c|}{ Category D } \\
\hline$n$ & $\bar{L}_{A A}$ & $s_{A A}$ & $n$ & $\bar{L}_{A B}$ & $s_{A B}$ & $n$ & $\bar{L}_{A C}$ & $s_{A C}$ & $n$ & $\bar{L}_{A D}$ & $s_{A D}$ \\
\hline \multicolumn{12}{|c|}{ The Vilnius-Kaunas highway (A1) } \\
\hline 14 & 17.22 & 20.40 & 22 & 3.91 & 5.85 & 11 & 2.16 & 4.04 & 66 & 2.39 & 1.70 \\
\hline \multicolumn{12}{|c|}{ The Kaunas-Klaipeda highway (A1) } \\
\hline 13 & 25.88 & 22.54 & 36 & 8.84 & 8.45 & 12 & 4.33 & 3.01 & 65 & 2.88 & 2.91 \\
\hline \multicolumn{12}{|c|}{ The Vilnius-Kaunas-Klaipeda highway (A1) } \\
\hline 27 & 21.39 & 20.49 & 58 & 6.97 & 7.46 & 23 & 3.77 & 3.50 & 131 & 2.63 & 2.37 \\
\hline \multicolumn{12}{|c|}{ The Vilnius-Panevėžys highway (A2) } \\
\hline 2 & 32.78 & 31.57 & 11 & 15.40 & 10.61 & 3 & 9.63 & 3.54 & 34 & 4.10 & 2.86 \\
\hline \multicolumn{12}{|c|}{ The roads $A 1$ and $A 2$} \\
\hline 29 & 21.90 & 21.36 & 69 & 8.31 & 7.97 & 26 & 4.45 & 3.51 & 165 & 2.94 & 2.40 \\
\hline \multicolumn{12}{|c|}{ The Panevėžys-Radviliškis-Šiauliai highway (A9) } \\
\hline 5 & 17.34 & 6.48 & 5 & 9.24 & 9.06 & 6 & 3.82 & 1.98 & 81 & 1.80 & 0.99 \\
\hline \multicolumn{12}{|c|}{ The Šiauliai-Kretinga-Palanga highway (A11) } \\
\hline 4 & 58.40 & 68.66 & 13 & 11.76 & 7.02 & 5 & 6.35 & 8.80 & 127 & 2.09 & 1.12 \\
\hline \multicolumn{12}{|c|}{ The roads $\mathrm{A} 9$ and $\mathrm{A} 11$} \\
\hline 9 & 35.59 & 46.03 & 18 & 11.06 & 7.64 & 11 & 4.97 & 6.11 & 208 & 1.98 & 1.07 \\
\hline \multicolumn{12}{|c|}{ The roads $\mathrm{A} 2, \mathrm{~A} 9$ and $\mathrm{A} 11$} \\
\hline 11 & 35.08 & 33.24 & 29 & 12.71 & 8.73 & 14 & 5.97 & 4.75 & 242 & 2.28 & 1.32 \\
\hline \multicolumn{12}{|c|}{ All investigated roads (A1, A2, A9 and A11) } \\
\hline 38 & 25.35 & 24.16 & 87 & 8.88 & 7.89 & 37 & 4.60 & 3.98 & 373 & 2.40 & 1.66 \\
\hline
\end{tabular}

Notes:

1) The highway A1 (Vilnius-Kaunas-Klaipeda) obtained the status of the European road E85 in 1998; the section of the Vilnius-Kaunas highway A1 satisfied the requirements to the road of category 1 in 2001;

2) The roads A2, A9 and A11 (the route Vilnius-Panevėžys-Radviliškis-Šiauliai-Kretinga-Palanga) comprise the European road E272 since 1998; the road A17 did not exist in 2001.

On the examined roads, the distance between RSAs of category A $\left(\bar{L}_{A A}=25.4 \mathrm{~km}\right)$ was 2.85 times larger than the distance between the RSAs of categories A and B $\bar{L}_{A B}$ $\left(\bar{L}_{A B}=\bar{L}_{B B}=8.9 \mathrm{~km} ; \bar{L}_{A A} / \bar{L}_{A B}=2.85\right)$. The distance $\bar{L}_{A B}$ was larger than the distance $\bar{L}_{A C}$ between RSAs of categories A and C $\left(\bar{L}_{A C}=\bar{L}_{B C}=\bar{L}_{C C}=4.6 \mathrm{~km}\right)$ by 1.93 times $\left(\bar{L}_{A B} / \bar{L}_{A C}=1.93\right)$; The distance $\bar{L}_{A C}$ was larger than the distance $\bar{L}_{A D}$ between RSAs of categories A and $C\left(\bar{L}_{A D}=\bar{L}_{B D}=\bar{L}_{C D}=\bar{L}_{D D}=2.4 \mathrm{~km}\right)$ by 1.92 times $\left(\bar{L}_{A C} / \bar{L}_{A D}=1.92\right)$. The study has shown that the distance $L_{A A}$ between RSAs of category A was about 3 times the distance $L_{A B}$ between RSAs of categories A and B. This is clearly shown by the particular distribution pattern of RSAs along these highways in the schematic model (Figure 3a).

The investigation has revealed some specific spacing patterns of RSAs of categories A and B and B, C and D. Thus, the distance between RSAs of a higher category was two times as large as that between RSAs of a lower category. This is clearly shown by the schematic model of their location (Figure 3b).
The study has also shown that in 2001 RSAs were distributed at the roadside of Lithuanian highways according to a uniform system.

The research results for 2016 (Table 7) show some changes in the distribution pattern of RSAs because the distance between RSAs of category A has become smaller by 2.14 times (Tables 6 and 7): $\bar{L}_{A A} / \bar{L}_{A A}^{(I)}=25.35 / 11.86=2.14$. The distances between RSAs of categories B, C and D have not changed considerably: $\bar{L}_{B B} / \bar{L}_{B B}^{(I)}=8.88 / 6.97=1.27$; $\bar{L}_{C C} / \vec{L}_{C C}^{(I)}=4.60 / 4.05=1.14 ; \bar{L}_{D D} / \vec{L}_{D D}^{(I)}=2.40 / 2.27=1.06$ (where $\bar{L}^{(I)}$ is an average distance between RSAs in 2016). In 2016, the average distance between RSAs of various categories was decreasing, depending on the decrease in the RSA category as follows: $\bar{L}_{A A} / \bar{L}_{A B}^{(I)}=1.70$; $\bar{L}_{A B} / \bar{L}_{A C}^{(I)}=1.72 ; \bar{L}_{A C} / \bar{L}_{A D}^{(I)}=1.78$ (i.e. it decreased by two times).

The data of investigations (Tables 6 and 7) have shown that in 2016 a system of RSAs distribution differed from that observed in 2001 because the distances between RSAs became shorter. In this system, a certain similarity of $L_{A A}$, 
a)

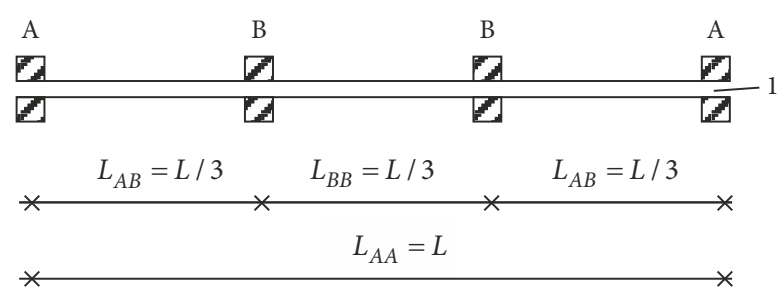

b)

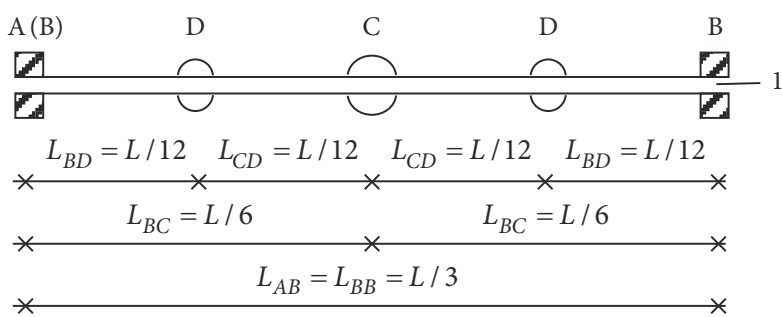

Figure 3. A model of the specific distribution of RSAs of categories A and B: a $-\bar{L}_{A A}=L$ is the distance between RSAs of category A; b - a model of the specific distribution of RSAs of categories A and B and B, C, D; 1 - is a motor road and RSAs located in the roadside areas (in 2001)

Table 7. The largest $L_{\max }$ and the shortest $L_{\min }$ distances between RSAs of categories A, B, C and D located by the roads A1, A2, A17, A9 and A11 and their statistical characteristics (2016)

\begin{tabular}{|c|c|c|c|c|c|c|c|c|c|c|c|c|c|c|c|c|c|c|c|}
\hline \multicolumn{20}{|c|}{$\begin{array}{l}\text { The statistical characteristics of RSAs categories and the distances between them (the number of individual values } n \text {, } \\
\left.\text { the largest } L_{\max } \text { and the smallest } L_{\min } \text { distances }[\mathrm{km}] \text {, the mean values } \bar{L}[\mathrm{~km}] \text { and standard deviations } s_{L}[\mathrm{~km}]\right)\end{array}$} \\
\hline \multicolumn{5}{|c|}{ Category A } & \multicolumn{5}{|c|}{ Category B } & \multicolumn{5}{|c|}{ Category C } & \multicolumn{5}{|c|}{ Category D } \\
\hline$n$ & $L_{A A}^{(\max )}$ & $L_{A A}^{(\min )}$ & $\bar{L}_{A A}$ & $s_{A A}$ & $n$ & $L_{A B}^{(\max )}$ & $L_{A B}^{(\min )}$ & $\bar{L}_{A B}$ & $s_{A B}$ & $n$ & $L_{A C}^{(\max )}$ & $L_{A C}^{(\min )}$ & $\bar{L}_{A C}$ & $s_{A C}$ & $n$ & $L_{A D}^{(\max )}$ & $L_{A D}^{(\min )}$ & $\bar{L}_{A D}$ & $s_{A D}$ \\
\hline \multicolumn{20}{|c|}{ The Vilnius-Kaunas-Klaipeda highway (A1): $311.0 \mathrm{~km}$} \\
\hline 46 & 59.1 & 0.4 & 12.52 & 14.97 & 37 & 51.1 & 0.1 & 6.73 & 9.52 & 134 & 22.1 & 0.1 & 3.60 & 4.25 & 30 & 4.8 & 0.1 & 2.31 & 1.40 \\
\hline \multicolumn{20}{|c|}{ The Vilnius-Ukmergé-Panevėžys highway (A2): 127.5 km } \\
\hline 11 & 38.5 & 0.5 & 12.14 & 10.81 & 14 & 25.5 & 0.5 & 8.36 & 6.75 & 29 & 25.5 & 0.5 & 5.47 & 4.98 & 6 & 5.5 & 1.1 & 2.76 & 1.48 \\
\hline \multicolumn{20}{|c|}{ The highways A1 and A2, $438.5 \mathrm{~km}$} \\
\hline 57 & 59.1 & 0.4 & 12.45 & 14.17 & 51 & 51.1 & 0.1 & 7.17 & 8.81 & 163 & 25.5 & 0.1 & 3.94 & 4.43 & 36 & 5.5 & 0.1 & 2.38 & 1.40 \\
\hline \multicolumn{20}{|c|}{ The Panevėžys-Radviliškis-Šiauliai road (A9): 82.0 km } \\
\hline 9 & 31.9 & 0.5 & 9.11 & 10.0 & 8 & 11.15 & 0.9 & 5.25 & 3.77 & 21 & \begin{tabular}{|l|}
11.2 \\
\end{tabular} & 0.1 & 3.68 & 3.18 & 11 & 5.5 & 0.3 & 2.45 & 1.96 \\
\hline \multicolumn{20}{|c|}{ The Šiauliai-Kretinga-Palanga road (A11): $150.0 \mathrm{~km}$} \\
\hline 12 & 44.3 & 0.1 & 12.25 & 15.25 & 11 & 44.0 & 0.3 & 7.57 & 13.33 & 27 & 15.0 & 0.2 & 5.31 & 4.54 & 17 & 3.05 & 0.7 & 1.88 & 0.79 \\
\hline \multicolumn{20}{|c|}{ The roads A9 and A11: $232.0 \mathrm{~km}$} \\
\hline 21 & 44.3 & 0.1 & 10.90 & 13.06 & 19 & 44.0 & 0.3 & 6.59 & 10.28 & 48 & 15.0 & 0.1 & 4.38 & 3.82 & 28 & 5.5 & 0.3 & 2.11 & 1.37 \\
\hline \multicolumn{20}{|c|}{ The roads A2, A17, A9 and A11 (E272): $371.0 \mathrm{~km}$} \\
\hline 34 & 44.3 & 0.1 & 10.97 & 11.88 & 35 & 44.0 & 0.3 & 7.23 & 8.62 & 79 & 25.5 & 0.1 & 4.80 & 4.24 & 36 & 5.5 & 0.3 & 2.24 & 1.35 \\
\hline \multicolumn{20}{|c|}{ The roads $\mathrm{A} 1, \mathrm{~A} 2, \mathrm{~A} 17, \mathrm{~A} 9$ and $\mathrm{A} 11: 682.0 \mathrm{~km}$} \\
\hline 80 & 59.1 & 0.1 & 11.86 & 13.68 & 72 & 51.1 & 0.1 & 6.97 & 9.03 & 213 & 25.5 & 0.1 & 4.05 & 4.28 & 66 & 5.5 & 0.1 & 2.27 & 1.37 \\
\hline
\end{tabular}

Notes:

1) the A1 highway is the European road E85; after the reconstruction of this section (Vilnius-Kaunas), it was referred to highways;

2) the southern part of the road A17 $(11.5 \mathrm{~km})$ makes a part of the European road E272; the roads A2, A17, A9 and A11 make the European road E272.

$L_{A B}$ and $L_{B B}$ values could be observed in some cases, when either RSAs of category A or B or RSAs of category B or C were closer to each other. In 2016, the distances between RSAs of all categories satisfied the recommended values (Table 2).

For larger distances $\bar{L}$ between RSAs higher standard deviations $s_{L}$ have been found. The overage values of $\bar{L}$ and standard deviations $s_{L}$ of the above distances increased appropriately (Figures 4 and 5).

The results, given in Tables 6 and 7 and Figures 4 and 5, show that the lower the category of RSA, the shorter the distances between RSAs and the more uniform their distribution.
The data on the density of RSAs distribution along highways (Table 8) show that RSAs of category $\mathrm{C}$ are most densely distributed, while RSAs of category A are distributed 1.73 times as densely, RSAs of category B are distributed 2.48 times less densely and RSAs of category D are the least densely distributed (by 4.03 times less densely) RSAs.

In 2001-2016, a considerable number of RSAs having petrol (gas) stations (category C) were established. The number of RSAs of category D decreased because some of them established gas stations and became RSAs of category C. Some of B category RSAs were modernized and became RSCs of category A, while some of D category RSAs were eliminated. 


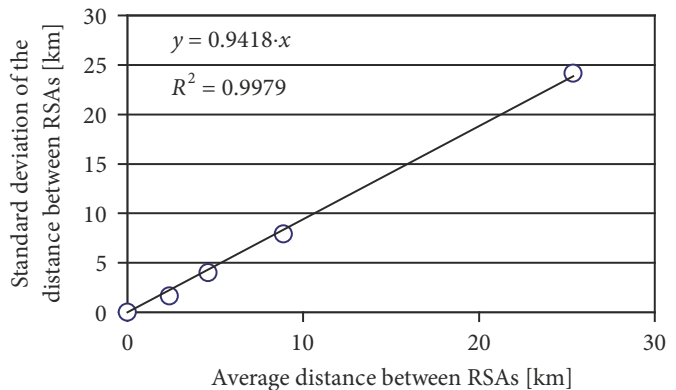

Figure 4. The relationship among the average distances $\bar{L}$ between RSAs and their standard deviations $s_{L}$ (the data for 2001)

The recommended distance between RSAs of category A in 1975 was $L_{A A}=110 \mathrm{~km}$, in $2001 \bar{L}_{A A}$ (Table 6) was equal to $25.35 \mathrm{~km}$, while in $2016 \bar{L}_{A A}$ (Table 7) was equal to $11.86 \mathrm{~km}$. These results have shown that a decrease in $\bar{L}_{A A}$ could be attributed to the time factor. In recent years, the distance $\bar{L}_{A A}$ has become more uniform, therefore, it is not likely to change considerably in the near future. The distances between RSAs of categories A, B, C and D stabilized in the period of 2001...2016 (Tables 6 and 7).

The analysis of the results has shown that using the suggested CM (Figure 1) and the developed algorithm (Figure 2) in the research allows for obtaining the objective values of the criteria describing TCs on highways. TCs on the examined road sections satisfied the specified TCs on their length sections: A1 - 83.3\%, A2 - 85.4\%, A9 $71.3 \%$ and A11 - 78.7\%. To describe TCs, the evaluation scale given below is offered (Table 9).

Based on the evaluation scale (Table 9), the authors determined TCs on the examined roads in 2016: A1 - good $\left(R_{T C}=83.3 \%\right), \mathrm{A} 2-$ very good $\left(R_{T C}=85.4 \%\right), \mathrm{A} 9-$ sufficient $\left(R_{T C}=71.3 \%\right)$ and $\mathrm{A} 11-\operatorname{good}\left(R_{T C}=78.7 \%\right)$.

\section{Conclusions}

TCs depend on travel safety, comfort, attractiveness and speed, while the latter depend on the state of pavement, road signs and road marking, as well as on using vehicles' radar speed signs and other devices, the location of RSAs along the roads and roadside landscape attractiveness. The operating conditions of pavement have an influence on the pavement condition, while the operating conditions of pavement and SP, as well as their service life, depend on the loads of HT facilities and their types, the climatic conditions and weather in the area, the materials of the pavement structural layers and soil and other factors (e.g. ground water level, sprinkling conditions and the roadbed condition (of road embankment or depression).

The research works and regulations specifying the TCs for road transport on motor roads do not always rely on a complex approach, which results in the situations when the designed and constructed roads do not appropriately perform the intended function. Therefore, the need arose for developing a model of the specified TCs on the roads by evaluating the criteria determining TCs from various

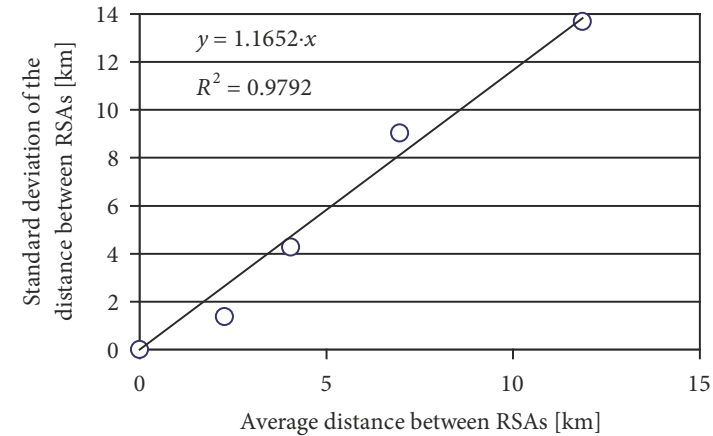

Figure 5. The relationship among the average distances $\bar{L}$ between RSAs and their standard deviations $s_{L}$ (the data for 2016)

Table 8 . The density of RSAs distribution along the highways (the data for 2016)

\begin{tabular}{|l|c|c|c|c|}
\hline \multirow{2}{*}{ Road number } & \multicolumn{4}{|c|}{$\begin{array}{c}\text { Distribution density of RSAs } \\
\text { along the highways in } 2016 \\
\text { [RSAs/100 km] }\end{array}$} \\
\cline { 2 - 5 } & A & B & C & D \\
\hline A1 & 10.77 & 6.11 & 18.33 & 3.22 \\
\hline A2 & 9.41 & 8.63 & 13.73 & 2.75 \\
\hline A1 and A2 & 10.38 & 6.84 & 16.99 & 2.96 \\
\hline A9 & 12.20 & 8.54 & 24.39 & 10.98 \\
\hline A11 & 8.84 & 6.12 & 17.69 & 5.44 \\
\hline A9 and A11 & 10.04 & 6.99 & 20.09 & 7.42 \\
\hline A2, A17, A9, A11 & 10.22 & 8.31 & 17.98 & 5.59 \\
\hline $\begin{array}{l}\text { All highways } \\
\text { (A1, A2, A17, A9, A11) }\end{array}$ & 10.47 & 7.30 & 18.14 & 4.50 \\
\hline
\end{tabular}

Table 9. The scale for evaluating TCs on highways

\begin{tabular}{|l|c|c|}
\hline \multicolumn{1}{|c|}{ TCs } & $\begin{array}{c}\text { The values } \\
\text { of TCs } \\
\text { [points] }\end{array}$ & $\begin{array}{c}\text { The complex criterion } \\
\text { of the compliance degree } \\
\text { of the planned TCs with the } \\
\text { specified TCs } R_{T C}[\%]\end{array}$ \\
\hline Excellent & 10 & $>95$ \\
\hline Very good & 9 & $85 \ldots 95$ \\
\hline Good & 8 & $75 \ldots 85$ \\
\hline Sufficient & 7 & $65 \ldots 75$ \\
\hline Satisfactory & 6 & $55 \ldots 65$ \\
\hline Critical & 5 & $50 \ldots 55$ \\
\hline Unsatisfactory & 4 & $<50$ \\
\hline
\end{tabular}

Note: the values of the criterion $R_{T C}$ presented in Table 9 show on which road length $L$ section $L_{n}$ [\%] the conditions of travel comply with the specified TCs: $R_{T C}=100 \cdot L_{n} / L$ [\%] ( $L$ is the total road length $[\mathrm{km}] ; L_{n}$ is the road length section $[\mathrm{km}]$ satisfying the specified TCs).

perspectives. This model is offered in the present work (Figure 1).

The TCs on motor roads based on the suggested CM (Figure 1) can be achieved by ensuring the specified width of the roads and their protected zones, as well as the width of the road pavement, roadway and shoulders, road pavement roughness and the admissible rutting and pavement 
destruction level. The criteria describing the road category and geometric parameters (i.e. length of the radii of the vertical, convex and concave curves and cross slopes of pavement and shoulders), as well as the average distances between the RSAs, not exceeding the distances recommended by the authors and the value of the roadside landscape aesthetic attractiveness criterion $A_{i}$ equal to $A_{i}=3$, should be also guaranteed.

The geometric criteria of the examined roads completely $(100 \%)$ satisfied the requirements of regulations in 2016. The TCs of $99.3 \%$ of the section length of highway A1 pavement satisfied the requirements, while on the remaining roads only $78.7 \ldots 85.4 \%$ of these requirements were satisfied. On the highways A1 and A2, $Y_{I R I}^{(\text {perm })}, H_{\text {perm }}$ and $D_{\text {perm }}$ admissible values of their condition criteria $Y_{I R I}, H$ and $D$ can be guaranteed if their pavement is repaired in time. The time periods between pavement repairs on these roads were reduced from $T_{d}=14$ years (in 1987) to $T_{d}=8$ years (in 2015). These periods are longer for highways A9 and A11, and their admissible pavement condition values are not always guaranteed.

The examination of the pavement condition on the highways $\mathrm{A} 1$ and $\mathrm{A} 2$ has shown that under the conditions of the increasing road traffic intensity and the percentage of HT on these roads, close relationship between the pavement roughness $Y_{I R I}$ and the criteria $D$ and $H$ remains unchanged. The critical values of the criteria $Y_{I R I}, D$ and $H$, ensuring comfort of travel, as well as good TCs on these roads, have been determined.

The examination of aesthetic attractiveness of roadside landscape described by the criterion $A_{i}$ allowed the authors to state that for $71.3 \ldots 92.2 \%$ of the roads' length the value of this criteria was rather high $\left(A_{i}=3\right)$. For the remaining sections of the roads and for the examined section (of $11.5 \mathrm{~km}$ ), the lower landscape attractiveness $\left(A_{i}=2\right)$ was found.

In the schematic model (Figure 3), the RSAs are divided into categories based on the planned time of rest as follows: from category A (the rest time $t \geq 10 \mathrm{~h}$ ) to category $\mathrm{D}(t<0.5 \mathrm{~h})$. The investigations (2001) show that the RSAs of categories A and B were distributed along the highways according to one particular schematic model (Figure 3a), while the RSAs of categories B, C and D were distributed according to another model (Figure $3 \mathrm{~b}$ ).

The authors have found that, in 2016, the RSAs of category $\mathrm{C}$, having cafes or gas stations, were most closely spaced along the examined roads, while the RSAs of category $\mathrm{D}$ were rarely distributed in this manner. When traffic intensity increased, a large number of the RSAs having gas stations emerged, while some of RSAs of category D established gas stations and became RSAs of category $\mathrm{C}$. The distances between RSAs of all categories (A, B, C and D) complied with the recommended distances (Table 2). It has been found that in 2016, with raising the RSAs category from $\mathrm{D}$ to $\mathrm{A}$, the distances $\bar{L}$ between the considered RSAs also increased by about 2 times (similar to the condition described in the schematic model) (Figure 3b).
The larger the distances $\bar{L}$, the larger the standard deviations $s_{L}$ of the distances between RSAs. The decrease in the distances between RSAs of category A, $\bar{L}_{A A}$ in 1975...2016 can be attributed to the time factor.

The analysis of the obtained results has shown that the developed model (Figure 1) allows for objective determination of the real TCs on highways. Using the evaluation scale (Table 9), the authors have determined the quality of TCs on the examined motor roads in warm seasons in 2016. They were as follows: A1 - good, A2 - very good, A9 - sufficient and A11 - good.

It can be recommended to use the developed model (Figure 1) and the applied algorithm (Figure 2) for checking the highways, which had not been examined yet, and for determining the quality of TCs on these roads, based on the values of the criterion $R_{T C}$ (Table 9). When TCs are unsatisfactory, the criterion $R_{T C}$ value does not reach $R_{T C}>65 \%$. Therefore, it is recommended to renew road sections (in the priority order), whose one or more criterion values of TCs (Table 1) do not comply with their specified values (Table 2), so that they would satisfy the requirements. In modernizing particular road sections, it should be sought that the values of the criterion $R_{T C}$ on the renewed road sections would be $R_{T C}>65 \%$.

\section{References}

Ai, C.; Tsai, Y.-C. J. 2015. Critical assessment of an enhanced traffic sign detection method using mobile LiDAR and INS technologies, Journal of Transportation Engineering 141(5). https://doi.org/10.1061/(ASCE)TE.1943-5436.0000760

Bertulienè, L.; Juknevičiūtė-Žilinskienè, L.; Sivilevičius, H.; Laurinavičius, A. 2018. Interaction of physical parameters and the strength of frost blanket course in road pavement structure, The Baltic Journal of Road and Bridge Engineering 13(4): 416-428. https://doi.org/10.7250/bjrbe.2018-13.426

Budriūnas, A. R.; Éringis, K. 2000. Kraštovaizdžio estetinio rekreacinio vertinimo metodika. Vilnius: Botanikos instituto leidykla. 38 p. (in Lithuanian).

Chamorro, A.; Tighe, S. L. 2015. Optimized maintenance standards for unpaved road networks based on cost-effectiveness analysis, Transportation Research Record: Journal of the Transportation Research Board 2473: 56-65.

https://doi.org/10.3141/2473-07

Chu, C.; Chung, K. 2016. A framework model for assessing sustainability strategies for tourism green supply chain management, Journal of Testing and Evaluation 44(3): 1390-1399. https://doi.org/10.1520/JTE20140196

Dell'Acqua, G. 2015. Modeling driver behavior by using the speed environment for two-lane rural roads, Transportation Research Record: Journal of the Transportation Research Board 2472: 83-90. https://doi.org/10.3141/2472-10

Elbagalati, O.; Elseifi, M. A.; Gaspard, K.; Zhang, Z. 2016. Prediction of in-service pavement structural capacity based on traffic-speed deflection measurements, Journal of Transportation Engineering 142(11).

https://doi.org/10.1061/(ASCE)TE.1943-5436.0000891

Geng, L.; Wang, X.; Ren, R.; Chen, F.; Yang, X. 2014. Performance evaluation of dense mixtures with stabilised rubber modified asphalt, Road Materials and Pavement Design 15(4): 953-965. https://doi.org/10.1080/14680629.2014.924426 
Haas, R; Tighe, S.; Falls, L. 2006. Determining return on long-life pavement investments, Transportation Research Record: Journal of the Transportation Research Board 1974: 10-17. https://doi.org/10.3141/1974-04

Han, D.; Do, M. 2016. Evaluation of socio-environmental effects considering road service levels for transportation asset management, Journal of Testing and Evaluation 44(1): 679-691. https://doi.org/10.1520/JTE20140484

LAKD. 2007. Automobilių keliu standartizuotų dangu konstrukciju projektavimo taisykles KPT SDK 07. Lietuvos automobiliu kelių direkcija (LAKD). (in Lithuanian).

LAKD. 2014. Kelių priežiūros vadovas. I dalis. Automobilių keliu priežiūros normatyvai KPV PN-14. Lietuvos automobilių kelių direkcija (LAKD). (in Lithuanian).

LAKD. 2008. Keliu techninis reglamentas KTR 1.01:2008. Lietuvos automobilių kelių direkcija (LAKD). (in Lithuanian).

Lee, J.; Nam, B.; Abdel-Aty, M. 2015. Effects of pavement surface conditions on traffic crash severity, Journal of Transportation Engineering 141(10).

https://doi.org/10.1061/(ASCE)TE.1943-5436.0000785

Lin, C.-T.; Goay, Y.-H. 2016. Evaluating the perceived relational benefits of travel agents on managing relationships with national tourism organization abroad offices: an empirical study, Journal of Testing and Evaluation 44(5): 1892-1903. https://doi.org/10.1520/JTE20140483

Mallick, R. B.; Li, H.; Harvey, J.; Myers, R.; Veeraragavan, A.; Reck, N. 2015. Pavement life-extending potential of geosynthetic-reinforced chip seal with high-reflectivity aggregates, Transportation Research Record: Journal of the Transportation Research Board 2474: 19-29. https://doi.org/10.3141/2474-03

Mathew, B. S.; Isaac, K. P. 2014. Optimisation of maintenance strategy for rural road network using genetic algorithm, International Journal of Pavement Engineering 15(4): 352-360. https://doi.org/10.1080/10298436.2013.806807

Mturi, G. A. J.; O’Connell, J.; Zoorob, S. E.; De Beer, M. 2014. A study of crumb rubber modified bitumen used in South Africa, Road Materials and Pavement Design 15(4): 774-790. https://doi.org/10.1080/14680629.2014.910130

Mubaraki, M. 2014. Third-order polynomial equations of municipal urban low-volume pavement for the most common distress types, International Journal of Pavement Engineering 15(4): 303-308. https://doi.org/10.1080/10298436.2012.756486

Mun, S. 2014. Inversion analysis to determine design parameters for reliability assessment in pavement structures, Canadian Journal of Civil Engineering 41(10): 845-855. https://doi.org/10.1139/cjce-2013-0507

Neill, J. M.; Hurwitz, D. S.; Olsen, M. J. 2016. Alternative information signs: evaluation of driver comprehension and visual attention, Journal of Transportation Engineering 142(1). https://doi.org/10.1061/(ASCE)TE.1943-5436.0000807

Pellecuer, L.; Assaf, G. J.; St-Jacques, M. 2014. Influence of pavement condition on environmental costs, Journal of Transportation Engineering 140(10): 04014050.

https://doi.org/10.1061/(ASCE)TE.1943-5436.0000721

Petkevičius, K. 2008. Automobiliu keliu asfaltbetonio dangos būkles tyrimai ir ju rezultatu taikymas: habilitacijos procedūrai teikiamu mokslo darbu apžvalga. Vilnius: Technika. 39 p. (in Lithuanian).

Petkevičius, K.; Christauskas, J.; Petkevičienè, B. 2006. Principles of rational dislocation of road infrastructure objects on the main and national roads, The Baltic Journal of Road and Bridge Engineering 1(2): 93-102.
Praticò, F. G. 2015. Simple equations for cost of premature failure of flexible pavements in low-volume roads, Transportation Research Record: Journal of the Transportation Research Board 2474: 73-81. https://doi.org/10.3141/2474-09

Qin, X.; Gao, L.; Shen, Y. 2016. Road landscape space enclosure scale and sequence characteristics based on human aesthetic perception and psychological experience, Journal of Testing and Evaluation 44(2): 734-743. https://doi.org/10.1520/JTE20150227

Qin, X.; He, Z.; Samra, H. 2015. Needs assessment of rural emergency medical services, Transportation Research Record: Journal of the Transportation Research Board 2513: 30-39. https://doi.org/10.3141/2513-04

Russo, F.; Biancardo, S. A.; Dell'Acqua, G. 2014. Road safety from the perspective of driver gender and age as related to the injury crash frequency and road scenario, Traffic Injury Prevention 15(1): 25-33. https://doi.org/10.1080/15389588.2013.794943

Samuchovienè, O.; Godienè, G.; Braga, A.; Matijošaitienė, I.; Vitkienè, J.; Kamičaitytè-Virbašienè, J.; Nemaniūtè-Gužienè, J.; Bugenienè, S.; Radvilavičius, R. 2013. Kraštovaizdžio formavimo gairès valstybiniams keliams ir geležinkeliams. Kaunas: Lutute. 132 p. (in Lithuanian).

Sivilevičius, H.; Vansauskas, V. 2013. Research and evaluation of ruts in the asphalt pavement on Lithuanian highways, Journal of Civil Engineering and Management 19(5): 609-621. https://doi.org/10.3846/13923730.2013.817481

Solatifar, N.; Kavussi, A.; Abbasghorbani, M.; Sivilevičius, H. 2017. Application of FWD data in developing dynamic modulus master curves of in-service asphalt layers, Journal of Civil Engineering and Management 23(5): 661-671. https://doi.org/10.3846/13923730.2017.1292948

Vislavičius, K.; Sivilevičius, H. 2013. Effect of reclaimed asphalt pavement gradation variation on the homogeneity of recycled hot-mix asphalt, Archives of Civil and Mechanical Engineering 13(3): 345-353. https://doi.org/10.1016/j.acme.2013.03.003

Wang, F.; Easa, S. 2016. Analytical evaluation of ride comfort on asphalt concrete pavements, Journal of Testing and Evaluation 44(4): 1671-1682. https://doi.org/10.1520/JTE20140339

Yaromko, V. N. 2008. O sovershenstvovanii proektirovaniya dorozhnyh odezhd nezhestkogo tipa, Nauka i tehnika $v$ dorozhnoj otrasli 45(2): 28-32. (in Russian). 